\title{
A work on Port Management
}

\author{
Magdalene Peter, S. Fabiyola Kavitha
}

\begin{abstract}
Data innovation has turned into a basic piece of the quick and precise exchange and preparing of gigantic volumes of information handled in worldwide vehicle firms and port associations. The correct administration of frameworks, which procedure this data and convey it to the individuals who oversee port activities, is essential for productive vehicle. This clarifies why holder following frameworks are given high need among operational PC applications in ports. Researches the significance of data innovation and its job in improving the operational frameworks in freight taking care of. A PC reenactment model is created to think about two distinctive operational frameworks a holder terminal furnished with electronic gadgets versus a terminal without such gadgets.
\end{abstract}

\section{Keywords: Data Innovation, Frameworks, Exchange}

\section{INTRODUCTION}

Port is where offices are accommodated the boats and other Sea going Crafts to take cover, have offices for emptying and stacking, for fuelling, and for taking crisp waters and such offices as might be required by them[1],[3],[5].

Different kinds of Export\& Import payloads are dealt with at each Port for International Trade as the Port or potentially to the nation. The Import Cargos are the different kinds of Export and Import well as Coastal Trade. The Export Cargos are those freights which are stacked in a ship and leave payloads are taken care of at each Port for International Trade just as Coastal Trade[2 ],[4],[6]. The Import Cargos are those freights which are stacked approaching payload from outside the nation and are commonly emptied at the Port.

Undertaking freight and overwhelming lift payload may incorporate things, for example, producing gear, plant segments, control hardware, for example, generators and wind turbines, military hardware or practically some other larger than average or overweight load too enormous or too substantial to even consider fitting into a compartment. Dry payload is intended to convey cargo, for example, coal, completed steel or its fixings, grain, sand or rock, or comparative materials. Freight ships are typically developed of steel[7],[9],[11]. They have an external structure, an interior void that is fitted with substantial swaggers and cross supports or scantlings, and an inside payload box. The

Revised Manuscript Received on July 22, 2019.

Ms Magdalene Peter, Department of MBA, Bharath Institute of Higher Education and Research, Chennai, India.

Email: magdalene.bsb@gmail.com

Dr. S. Fabiyola Kavitha, Department of MBA, Bharath Institute of Higher

Education and Research, Chennai, India

Email: fabiyolakavitha@gmail.com external body of a jump can come in one of two setups. A rake scow has a bended bow to give less opposition when being pushed and is generally put at the leader of the tow. A case freight ship is normally put in the middle and back of the tow and can hold more payload. Mass freight is item payload that is shipped unpackaged in enormous amounts[8],[10],[12]. These freights are generally dropped or poured, with a gush or scoop container, as a fluid or as a mass of moderately little solids (for example grain, coal), into a mass transporter ship's hold, railroad vehicle, or tanker truck/trailer/semi-trailer body. Mass loads are named fluid or dry. Fluid freight flatboats are canal boats that transport petrochemicals, for example, styrene, benzene and methanol; fluid manure, including anhydrous smelling salts; refined items, including gas, diesel and stream fuel; dark oil items, for example, black-top, No. 6 fuel oil and Coker fuel; and pressurized items, for example, butane, propane and butadiene, which are shipped on the conduits from makers to end clients[13], [15],[17]

\section{RESEARCH METHODOLOGY}

\section{CHI-SQUARE TEST}

A chi-square test (likewise chi squared test or $\chi^{2}$ test) is any factual speculation test in which the examining circulation of the test measurement is a chi-square appropriation when the invalid theory is valid, or any wherein this is asymptotically valid, implying that the inspecting conveyance (if the invalid theory is valid) can be

$$
\chi^{2}=\Sigma(\mathrm{Oi}-\mathrm{Ei})^{2} / \mathrm{E}_{\mathrm{i}}
$$

Where $\chi^{2}=$ Chi-square

made to estimated a chi-square dispersion as intently as wanted by making the example size huge enough[14],[16], [18].

$$
\begin{aligned}
& \text { Formula for Chi-Square test } \\
& \qquad \begin{array}{l}
\mathrm{Oi}=\text { Observed Frequency } \\
\mathrm{Ei}=\text { Expected Frequency }
\end{array}
\end{aligned}
$$

\begin{tabular}{|c|c|c|c|}
\hline S.NO & PARTICULARS & $\begin{array}{l}\text { NO.OF } \\
\text { SHIPMENTS }\end{array}$ & PERCENTAGE \\
\hline 1 & Export & 73 & $61 \%$ \\
\hline 2 & Import & 47 & $39 \%$ \\
\hline 3 & Total & 120 & $100 \%$ \\
\hline
\end{tabular}

\section{DATA ANALYSIS AND INTERPRETATION}

Table 1- Type of The Shipment 


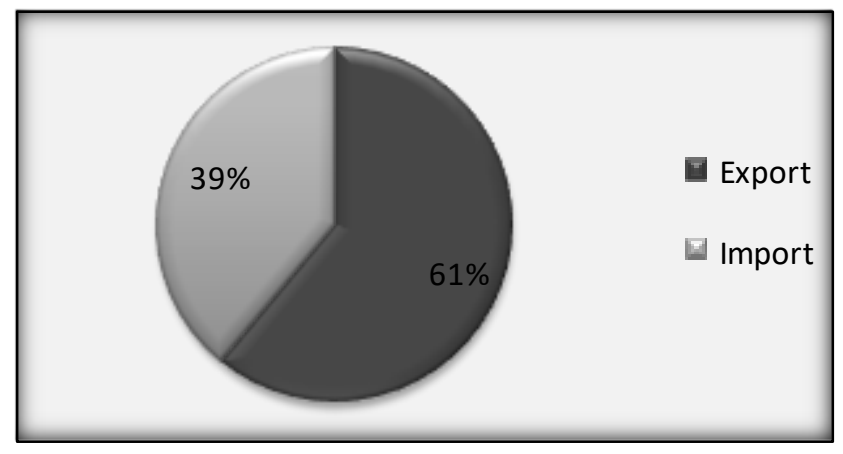

Figure 1- Type of The Shipment

Table 2- Mode of The Shipment

\begin{tabular}{|l|l|l|l|}
\hline S.NO & PARTICULARS & $\begin{array}{l}\text { NO.OF } \\
\text { SHIPMENTS }\end{array}$ & PERCENTAGE \\
\hline $\mathbf{1}$ & Air freight & 44 & $37 \%$ \\
\hline $\mathbf{2}$ & Sea freight & 76 & $63 \%$ \\
\hline $\mathbf{3}$ & Total & 120 & $100 \%$ \\
\hline
\end{tabular}

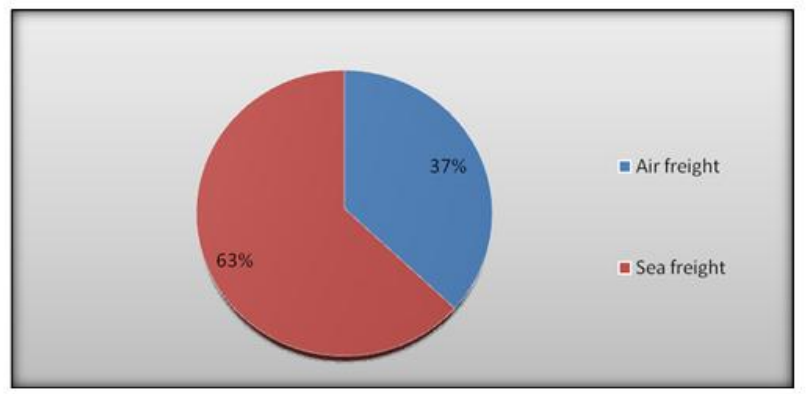

Figure 2- Mode of The Shipment

Table 3-Container load of The Shipment

\begin{tabular}{|l|l|l|l|}
\hline S.NO & PARTICULARS & $\begin{array}{l}\text { NO.OF } \\
\text { SHIPMENTS }\end{array}$ & PERCENTAGE \\
\hline $\mathbf{1}$ & LCL & 87 & $73 \%$ \\
\hline $\mathbf{2}$ & FCL & 33 & $27 \%$ \\
\hline $\mathbf{3}$ & Total & 120 & $100 \%$ \\
\hline
\end{tabular}

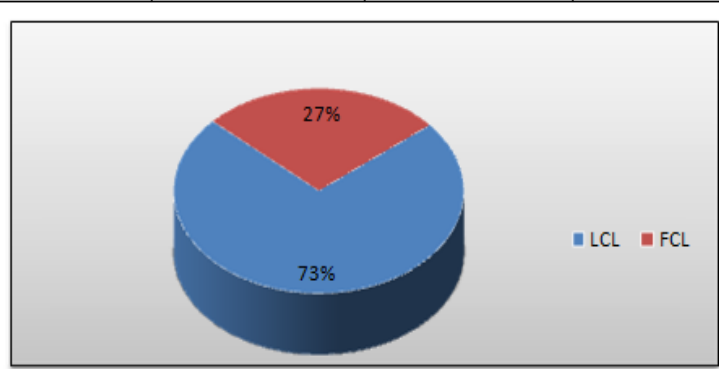

Figure 3- Container load of The Shipment
Table 4- Type Of Cargo Handled

\begin{tabular}{|l|l|l|l|}
\hline S.NO & PARTICULARS & $\begin{array}{l}\text { NO.OF } \\
\text { SHIPMENTS }\end{array}$ & PERCENTAGE \\
\hline $\mathbf{1}$ & Gaments & 34 & $28 \%$ \\
\hline $\mathbf{2}$ & Electronics & 33 & $28 \%$ \\
\hline $\mathbf{3}$ & Chemicals & 21 & $17 \%$ \\
\hline $\mathbf{4}$ & Perishables & 18 & $15 \%$ \\
\hline $\mathbf{5}$ & Others & 14 & $12 \%$ \\
\hline $\mathbf{6}$ & Total & 120 & $100 \%$ \\
\hline
\end{tabular}

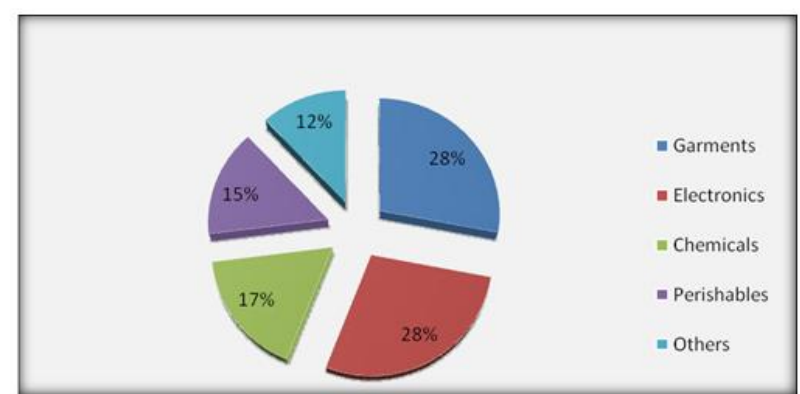

Figure 4- Type Of Cargo Handled

Table 5- Weight Of Cargo Handled

\begin{tabular}{|l|l|l|l|}
\hline S.NO & PARTICULARS & $\begin{array}{l}\text { NO.OF } \\
\text { SHIPMENTS }\end{array}$ & PERCENTAGE \\
\hline $\mathbf{1}$ & $0-100 \mathrm{Kgs}$ & 24 & $20 \%$ \\
\hline $\mathbf{2}$ & $100-200 \mathrm{Kgs}$ & 32 & $27 \%$ \\
\hline $\mathbf{3}$ & $200-300 \mathrm{Kgs}$ & 10 & $8 \%$ \\
\hline $\mathbf{4}$ & $300-400 \mathrm{Kgs}$ & 9 & $7 \%$ \\
\hline $\mathbf{5}$ & $\begin{array}{l}\text { More than } 400 \\
\text { Kgs }\end{array}$ & 45 & $38 \%$ \\
\hline $\mathbf{6}$ & Total & 120 & $100 \%$ \\
\hline
\end{tabular}

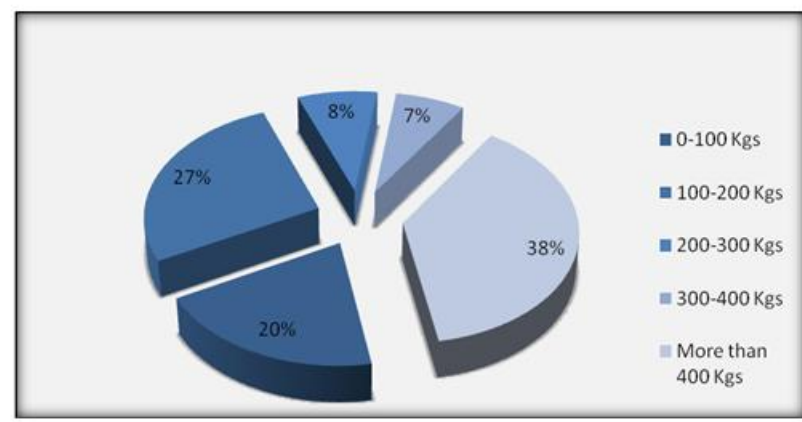

Figure 5- Weight Of Cargo Handled 
Table 6- Type Of The Package Used

\begin{tabular}{|l|l|l|l|}
\hline S.NO & PARTICULARS & $\begin{array}{l}\text { NO.OF } \\
\text { SHIPMENTS }\end{array}$ & PERCENTAGE \\
\hline $\mathbf{l}$ & Carton & 48 & $40 \%$ \\
\hline $\mathbf{2}$ & Pallet & 29 & $24 \%$ \\
\hline $\mathbf{3}$ & Drum & 16 & $13 \%$ \\
\hline $\mathbf{4}$ & Bag & 23 & $20 \%$ \\
\hline $\mathbf{5}$ & Others & 04 & $3 \%$ \\
\hline $\mathbf{6}$ & Total & 120 & $100 \%$ \\
\hline
\end{tabular}

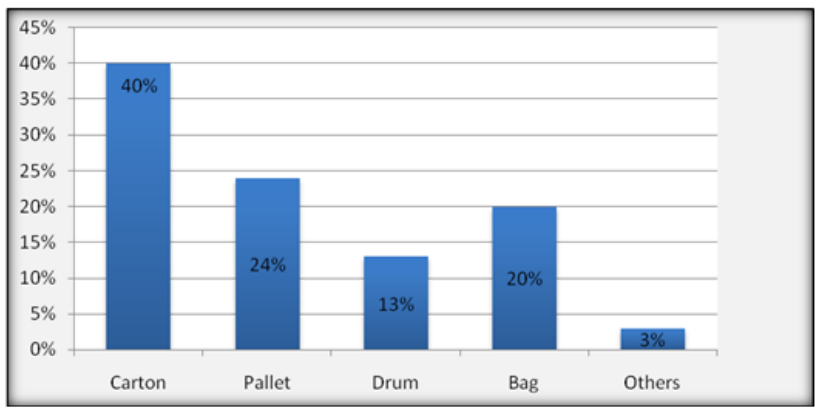

Figure 6- Type Of The Package Used

\section{A. Chi-Square}

$\mathbf{H}_{\mathbf{0}}$ : There is no significant association between the weight of the cargo and the equipment used to handle it.

$\mathbf{H}_{\mathbf{1}}$ : There is significant association between the weight of the cargo and the equipment used to handle it.

\section{Formula:}

The CHI-SQUARE test is carried out using the formula, $\chi^{2}=\left(\mathrm{O}_{\mathrm{ij}}-\mathrm{E}_{\mathrm{ij}}\right)^{2} / \mathrm{E}_{\mathrm{i}}$

\begin{tabular}{|l|l|l|l|l|l|}
\hline Factors & Fork lift & RTG & $\begin{array}{l}\text { Mobile } \\
\text { crane }\end{array}$ & Others & Total \\
\hline $0-100$ & 7 & 3 & 13 & 1 & $\mathbf{2 4}$ \\
\hline $100-200$ & 10 & 6 & 15 & 1 & $\mathbf{3 2}$ \\
\hline $200-300$ & 3 & 2 & 5 & 0 & $\mathbf{1 0}$ \\
\hline $300-400$ & 2 & 1 & 6 & 0 & $\mathbf{9}$ \\
\hline $\begin{array}{l}\text { More than } \\
400\end{array}$ & 13 & 6 & 24 & 2 & $\mathbf{4 5}$ \\
\hline Total & $\mathbf{3 5}$ & $\mathbf{1 3}$ & $\mathbf{6 3}$ & $\mathbf{4}$ & $\mathbf{1 2 0}$ \\
\hline
\end{tabular}

Calculated $\chi 2$ value $=3.1274$

Degree of Freedom $=(\mathrm{R}-1)(\mathrm{C}-1)=12$

Level of significance $=5 \%$

Table $\chi 2$ value $=21.026$

From the calculations it is found that the calculated value is lesser than the table value, therefore the hypothesis is good to hold.

Hence the Null hypothesis is accepted.

\section{Inference:}

There is no significant association between the weight of the cargo and the equipment used to handle it.

\section{B. One-Way Anova}

Calculations Based On One-Way Anova Transportation Arrangement By Company And Damage Occurrence Of Cargo.

Null Hypothesis $\left(\mathbf{H}_{\mathbf{0}}\right)$ : There is no significant association transportation arrangement by company and damage occurrence of cargo.

Alternative Hypothesis $\left(\mathbf{H}_{1}\right)$ : There is significant association transportation arrangement by company and damage occurrence of cargo.

Table 7 - Showing relationship between transportation arrangement by company and damage occurrence of cargo. 
A Work on Port Management

\begin{tabular}{|l|c|c|c|c|c|}
\hline Factors & Yes & No & Total & $(\mathbf{X} 1)^{2}$ & $(\mathbf{X} 2)^{2}$ \\
\hline Strongly agree & 26 & 13 & 39 & 676 & 169 \\
\hline Agree & 34 & 22 & 56 & 1156 & 484 \\
\hline $\begin{array}{l}\text { Neither agree nor } \\
\text { disagree }\end{array}$ & 9 & 8 & 17 & 81 & 64 \\
\hline Disagree & 2 & 3 & 5 & 4 & 9 \\
\hline Strongly disagree & 1 & 2 & 3 & 1 & 4 \\
\hline Total & 72 & 48 & 120 & 1918 & 730 \\
\hline
\end{tabular}

$\frac{[7675]}{\text { Sqrt }[(5330) *(12330)]}$
$\frac{[7675]}{\text { Sqrt [65718900] }}$
$\frac{[7675]}{8106.71}$
$=\mathbf{0 . 9 4 6 7}$

This correlation has stronger relationship.

\section{Inference:}

There is a strong relationship between the type of the container used and type of the package of the cargo handled.

STEP 1: $\quad \mathrm{N}=8$

STEP 2: $\mathrm{T}^{2} / \mathrm{N}=(120)^{2} / 8=1800$

STEP3: SUM OF SQUARES $=1918+730=2648$

STEP 4: TOTAL SUM OF SQUARES $($ SST $)=2648-1800=$ 848

STEP 5: SUM OF SQUARES COLUMNS $(\mathrm{SSC})=(72)^{2} / 2$ $+(48)^{2} / 2-1800=1152-1800=194$

STEP 6: SSE $=$ SST $-\mathrm{SSC}=848-1944=1096$

\begin{tabular}{|l|lr|l|l|l|}
\hline Sources & $\begin{array}{l}\text { Sum of } \\
\text { squares }\end{array}$ & $\begin{array}{l}\text { Degree } \\
\text { freedom }\end{array}$ & $\begin{array}{l}\text { Mean } \\
\text { square }\end{array}$ & F ratio \\
\hline Columns & 1944 & $\mathrm{C}=(2-1)=1$ & 1944 & 0.0805 \\
\hline Error & 1096 & $(\mathrm{~N}-\mathrm{C})=8-1=7$ & 156.57 & $(1,7)$ \\
\hline
\end{tabular}

Calculated $\mathrm{F}=0.0805$

Table value @ 5\%

Table F $(1,7)$

$=5.59$

\section{Conclusion:}

Calculated F < Table F

Therefore $\mathrm{H}_{0}$ is accepted

\section{Inference:}

There is no significant association transportation arrangement by company and damage occurrence of cargo.

\section{Coefficient Of Correlation}

$\mathrm{X}$ : Type of the package

$\mathrm{Y}$ : Type of the container

$$
r=\frac{n \sum x y-\left(\sum x\right)\left(\sum y\right)}{\sqrt{n\left(\sum x^{2}\right)-\left(\sum x\right)^{2}} \sqrt{n\left(\sum y^{2}\right)-\left(\sum y\right)^{2}}}
$$

[5*4415-(120)(120)]

Sqrt $[(5 * 3946)-(14400)(5 * 5346)-(14400)]$

\section{RESULTS}

- The organization handles $61 \%$ fare shipments and $39 \%$ of import shipments.

Around $63 \%$ of the shipments are dealt with via ocean just, rest through air.

$73 \%$ of the shipments are stacked by LCL and $27 \%$ by FCL holders[19],[21],[23].

$\square$ The payload took care of are $28 \%$ of articles of clothing and hardware each, $17 \%$ synthetic concoctions, $15 \%$ perishables and $12 \%$ other kind of freight.

$38 \%$ of the shipments are in excess of $400 \mathrm{kgs}$ of weight, $27 \%$ of freight are $100-200 \mathrm{kgs}, 20 \%$ are $0-100 \mathrm{kgs}, 8 \%$ are $200-300 \mathrm{kgs}$ and $7 \%$ are $300-400 \mathrm{kgs}$ of load

It is discovered that $40 \%$ of shipments are pressed in container, $24 \%$ in bed, $20 \%$ in sack, $13 \%$ in drum and $3 \%$ of shipments are stuffed by different modes.

For the carriage of payload, 55\% of shipments are brought through $20 \mathrm{ft}$ holder, $22 \%$ through $40 \mathrm{ft}, 12 \%$ through fridge, $7 \%$ through 3D squares and $4 \%$ through open top compartments are utilized.

The hardware used to deal with payload is $53 \%$ by versatile crane, $29 \%$ by fork lift, $15 \%$ by RTG and $3 \%$ by different methods of gear.

A exceedingly fulfilled level of about $89 \%$ of the shipments are dealt with great hardware and $11 \%$ with less proficient gear[20],[22], [24].

$61 \%$ of shipments require under 2 people, $32 \%$ requires $2-4$ people and $7 \%$ requires multiple people for taking care of payload.

Most of the shipments are acknowledged with no harm, in addition $98 \%$ of shipments. 
It is discovered that $28 \%$ unequivocally concur, $39 \%$ concur, $16 \%$ neither concur nor dissent, $13 \%$ differ and $4 \%$ emphatically differ to the compartments condition about the qualification for use.

$28 \%$ unequivocally concur, $33 \%$ concur, $23 \%$ neither concur nor dissent, $10 \%$ differ and $6 \%$ emphatically differ that the shipments are utilizing proper bundles.

The recognizable proof numbers on the load are set apart with no mix-ups which contributes $95 \%$.

$60 \%$ of the shipments are moved through organization and $40 \%$ through the customer itself to the last goal.

$31 \%$ unequivocally concur, $41 \%$ concur, $17 \%$ neither concur nor dissent, $7 \%$ differ and $4 \%$ emphatically differ that the shipments are taken care of through great hardware.

$32 \%$ firmly concur, $47 \%$ concur, $14 \%$ neither concur nor dissent, $4 \%$ differ and $3 \%$ unequivocally differ that transportation happens with no harm.

A high level of about $83 \%$ of shipments land to port on right time, while rest arrives late[25],[27],[29].

A signalman is utilized while taking care of freight for about $73 \%$ of shipments.

The wellbeing measures are taken on risky merchandise the condition is acknowledged alike $20 \%$ emphatically concur, $30 \%$ concur, $35 \%$ neither concur nor dissent, $10 \%$ differ and $5 \%$ firmly oppose this idea

It is discovered that $76 \%$ of shipments are studied and $24 \%$ of the shipments are not reviewed by the surveyors.

From the chi - square test it is discovered that there is no critical relationship between the heaviness of the freight and the gear used to deal with it.

From the single direction ANOVA test it is affirmed that there is no huge affiliation transportation course of action by organization and harm event of freight.

From the coefficient of connection it is affirmed that there is a solid connection between the kind of the holder utilized and sort of the bundle of the load dealt with.

From the coefficient of relationship it is affirmed that there is solid positive connection between's gear utilized and security estimates taken on the payload.

\section{DISCUSSIONS}

- More import shipments can be taken in light of the fact that import can give more benefit than fare.
Machinery parts can be taken for fare/import which gives greatest benefit than some other merchandise.

The signalman ought to be utilized at all the vital spots for more secure development of freight.

Effective lifting hardware ought to be utilized appropriately.

The bundle of the payload ought to be made fittingly.

Special care ought to be taken on risky products.

Care must be taken while transportation. Security safeguards ought to be pursued.

Survey must be taken to affirm that every one of the shipments are acknowledged with no harm and with no off base distinguishing proof imprints[26],[28],[30].

\section{CONCLUSION}

Innovation has driven material and payload dealing with to an abnormal state. Many lifting hardware are utilized in taking care of load now a days made simpler treatment of freight.

Lion's share of the shipments are taken care of appropriately with no wasteful systems. Just a portion of the shipments require uncommon consideration. Every one of the factors of the payload taking care of methods are completed easily aside from a few. In any case, that is ordinary, since errors happen incidentally[31],[33]. In this way, on the dealing with procedure hardware utilization, signalman, compartments, weight of the freight, substance of the payload ought to be painstakingly watched and act in like manner. This will guarantee powerful load taking care of systems of the organization.

What's more, to my degree I had an incredible involvement in the load dealing with procedure and got information on the coordinations business.

\section{REFERENCES}

1) BharthVajan R., Ramachandran S.,Psychographic dimensions of training,2016,International Journal of Pharmacy and Technology,V-8,I-4,P-23727-23729

2) Balakrishnan P., Bharthvajan R.,A study on human resource planning in hospitals in Chennai City,2014,International Journal of Applied Engineering Research,V-9,I-22,P-7503-7507

3) Priyadarsini P., Bharthvajan R.,Role of emotional intelligence training programme in reducing the stress of the nurses,2014,International Journal of Applied Engineering Research,V-9,I-22,P-7411-7421

4) Kerinab Beenu G., Bharthvajan R.,Empirical analysis on the cosmetic buying behavior of young women in South India,2014,International Journal of Applied Engineering Research,V-9,I-22,P-7361-7366

5) Balakrishnan P., Bharthvajan R.,Whistling in the wind,2014,International Journal of Applied Engineering Research,V-9,I-22,P-7586-7593

6) Krishnan B., Peter M.,Health hazards of Indian Bpo employee-an alarming issue,2014,International Journal of Applied Engineering Research,V-9,I-22,P-7336-7341

7) Kerinab Beenu G.H., Peter M.,Role of insurance in economic development,2014,International Journal of Applied Engineering Research,V-9,I-22,P-7532-7539

8) Balakrishnan P., Peter M Priyadarsini P.,Efficiency of safety measures for wellbeing of employees in manufacturing 
industry,2014,International Journal of Applied Engineering Research,V-9,I-22,P-7376-7382

9) Anbarasi M., Praveen Kumar S.,Online sales promotions of herbal products and its effectiveness towards tanisha.com,2019,Indian Journal of Public Health Research and Development,V-10,I-1,P-195-200

10) Anbarasi M., Praveen Kumar S.,Various online marketing and promotions strategies to improve the validation towards the organic products in the pharmaceutical sectors,2019,Indian Journal of Public Health Research and Development, V-10,I-1,P-263-269

11) Loganathan R., Praveen Kumar S.,Grievance handling a key factor for solving issues of employees in an organization,2014,International Journal of Applied Engineering Research,V-9,I-22,P-7483-7491

12) Loganathan R., Praveen Kumar S.,Study on preference of private label brands in super and Hypermarkets,2014,International Journal of Applied Engineering Research,V-9,I-22,P-7327-7335

13) Smitha M., Praveen Kumar S.,Understanding stress and its managementamong the nurses in Chennai city,2014,International Journal of Applied Engineering Research,V-9,I-22,P-7560-7565

14) Kerinab Beenu G.H., Praveen Kumar S.,A study on the investment behavior of Chennai investors in mutual fund schemes,2014,International Journal of Applied Engineering Research,V-9,I-22,P-7520-7525

15) Loganathan R., Praveen Kumar S.,Retention strategies key for organizational productivity,2014,International Journal of Applied Engineering Research,V-9,I-22,P-7443-7447

16) Pavithra J., Ganesan M., Brindha G.,State wise analysis of microfinance sector in India,2016,International Journal of Pharmacy and Technology,V-8,I-4,P-23417-23432

17) Pavithra J., Ganesan M.,A comparative study on microfinance in India and abroad,2016,International Journal of Applied Business and Economic Research,V-14,I-8,P-5471-5476

18) Pavithra J., Ganesan M.,A study on awareness and impact of micro-financial schemes,2016,International Journal of Applied Business and Economic Research,V-14,I-8,P-5449-5460

19) Senthilmurugan P., Pavithra J.,Consumer preference towards organised retailing with reference to Big Bazaar,2014,International Journal of Applied Engineering Research,V-9,I-22,P-7469-7475

20) Senthilmurugan P., Pavithra J.,Implication of social media marketing in growing healthcare industry,2014,International Journal of Applied Engineering Research,V-9,I-22,P-7448-7456

21) Loganathan R., Pavithra J.,Consumer perception towards private label brand over other brands in super markets and hypermarkets,2014,International Journal of Applied Engineering Research,V-9,I-22,P-7355-7360

22) Kerinab Beenu G., Pavithra J.,Tradeâ€"off between liquidity and profitability in logistics industry,2014,International Journal of Applied Engineering Research,V-9,I-22,P-7398-7401

23) Kerinab Beenu G., Pavithra J.,A study on the prospective consumerâ€ $\mathrm{TM}_{\mathrm{S}}$ perception towards utility cars in Chennai city,2014,International Journal of Applied Engineering Research,V-9,I-22,P-7526-7531

24) Pavithra J., Dilli Babu P., Ambuli T.V.,A study on budgetary control at Maruti Service Masters, Chennai,2014,International Journal of Applied Business and Economic Research,V-12,I-2,P-151-161

25) Pavithra J., Dilli Babu P., Ambuli T.V.,A study on customer satisfaction of retro Garments Pvt Ltd, Chennai,2014,International Journal of Applied Business and Economic Research,V-12,I-2,P-381-391

26) Kerinab Beenu G.H., Pavithra J., Senthilmurugan P.,A study on the influence of promotional activities for TATA ARIA among consumers in Chennai,2014,International Journal of Applied Engineering Research,V-9,I-22,P-7572-7578

27) Vijayaragavan S.P.,An investigative expert that's general FBG sensors, International Journal of Mechanical Engineering and Technology,V-8,I-8,PP-1500-1505,Y-2017

28) Vijayaragavan S.P.,Equalization routing protocol for Wi-Fi sensor strategy,International Journal of Mechanical Engineering and Technology,V-8,I-8,PP-1662-1666,Y-2017

29) Karthik B., Kiran Kumar T.V.U., Vijayaragavan P., Bharath Kumaran E.,Design of a digital PLL using 0.35 $\hat{\mathrm{I}}^{1} / 4 \mathrm{~m}$ CMOS technology,Middle East Journal of Scientific Research,V-18,I-12,PP-1803-1806,Y-2013

30) Kanniga E., Selvaramarathnam K., Sundararajan M.,Kandigital bike operating system,Middle - East Journal of Scientific Research,V

31) Jasmin M., Vigneshwaran T., Beulah Hemalatha S.,Design of power aware on chip embedded memory based FSM encoding in FPGA,International Journal of Applied Engineering Research,V-10,I-2,PP-4487-4496,Y-2015

32) Jasmin M.,Optimization techniques for low power VLSI circuits,Middle East Journal of Scientific Research,V-20,I-9,PP-1082-1087,Y-2014

33) Jasmin M., Vigneswaran T.,Fuzzy controller for error control of on - Chip communication,2017 International Conference on Algorithms, Methodology, Models and Applications in Emerging Technologies, ICAMMAET 2017,V-2017-January,I-,PP-1-5,Y-2017

\section{AUTHORS PROFILE}

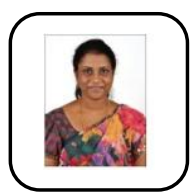

Ms Magdalene Peter Assistant Professor, Department of MBA, Bharath Institute of Higher Education and Research, Chennai, India.

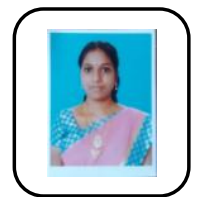

Dr. S. Fabiyola Kavitha Associate Professor, Department of MBA, Bharath Institute of Higher Education and Research, Chennai, India. 